\title{
Drop the Salt! Assessing the impact of a public health advocacy strategy on Australian government policy on salt
}

\author{
Jacqui Webster ${ }^{1,2, *}$, Elizabeth Dunford ${ }^{1,2}$, Sarah Kennington ${ }^{3}$, Bruce Neal ${ }^{1,2}$ and \\ Simon Chapman ${ }^{2}$ \\ 'The George Institute for Global Health, University of Sydney, PO Box M201, Missenden Road, Camperdown, \\ NSW 2050, Australia: ${ }^{2}$ Sydney Medical School, The University of Sydney, Sydney, New South Wales, \\ Australia: ${ }^{3}$ Independent Consultant, Sydney, Sydney, New South Wales, Australia
}

Submitted 4 April 2012: Final revision received 23 July 2012: Accepted 3 September 2012: First published online 22 November 2012

\begin{abstract}
Objective: In 2007 the Australian Division of World Action on Salt and Health (AWASH) launched a campaign to encourage the Australian government to take action to reduce population salt intake. The objective of the present research was to assess the impact of the Drop the Salt! campaign on government policy.

Design: A review of government activities related to salt reduction was conducted and an advocacy strategy implemented to increase government action on salt. Advocacy actions were documented and the resulting outcomes identified. An analysis of stakeholder views on the effectiveness of the advocacy strategy was also undertaken.

Settings: Advocacy activities were coordinated through AWASH at the George Institute for Global Health in Sydney.

Subjects: All relevant State and Federal government statements and actions were reviewed and thirteen stakeholders with known interests or responsibilities regarding dietary salt, including food industry, government and health organisations, were interviewed.

Results: Stakeholder analysis affirmed that AWASH influenced the government's agenda on salt reduction and four key outputs were attributed to the campaign: (i) the Food Regulation Standing Committee discussions on salt, (ii) the Food and Health Dialogue salt targets, (iii) National Health and Medical Research Council partnership funding and (iv) the New South Wales Premier's Forum on Fast Foods. Conclusions: While it is not possible to definitively attribute changes in government policy to one organisation, stakeholder research indicated that the AWASH campaign increased the priority of salt reduction on the government's agenda. However, a coordinated government strategy on salt reduction is still required to ensure that the potential health benefits are fully realised.
\end{abstract}

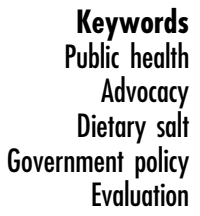

Keywords

Advocacy

Dietary salt

Evaluation

\section{Salt and bealth}

Australians are eating too much salt ${ }^{(1,2)}$ and it is widely accepted that excess dietary salt consumed throughout life contributes to a rise in blood pressure with age ${ }^{(3,4)}$, which in turn increases the risk of $\mathrm{CVD}^{(5)}$. CVD (predominantly heart attack and stroke) are the leading causes of death and disability in Australia ${ }^{(6)}$ and salt has also been implicated in a number of other major health problems ${ }^{(7)}$. There is consensus that reducing salt intake will have population-wide effects on blood pressure levels and the adverse health outcomes that result ${ }^{(8-10)}$.

\section{Government action to reduce salt in otber countries} A number of countries are implementing population-wide salt reduction programmes ${ }^{(11,12)}$. Most notably, Finland successfully reduced population salt intake in the 1970 s and in 2003 the UK launched a three-pronged strategy ${ }^{(13)}$ that has had a demonstrable impact and is estimated to be saving around 6000 lives annually ${ }^{(14,15)}$. These strategies include efforts to change individual behaviour in salt use and regulatory policies to limit salt used by the food industry, including in meals eaten outside the home. Two important elements of the UK work include strong government leadership and the establishment of voluntary salt targets for specific food categories. More recently, the USA and Canadian governments have launched proposals for national salt reduction strategies including targets for salt levels in foods and meals ${ }^{(16,17)}$.

\section{Role of advocacy organisations in salt reduction}

Organisations dedicated to advocating for salt reduction have played an important role in both the $\mathrm{UK}^{(18)}$ and 
the USA ${ }^{(19)}$. Since 2005 this advocacy has been promoted internationally ${ }^{(20)}$. A key objective of these advocacy organisations is to influence government policy. The work of Consensus Action on Salt and Health in the UK probably influenced the decision of the UK Food Standards Agency to adopt salt reduction as a goal $^{(21,22)}$ and there is advocacy activity by non-governmental organisations (NGO) in the majority of countries with salt reduction programmes ${ }^{(11)}$. Many of these organisations are now united internationally through World Action on Salt and Health and are likely to have had influence internationally, including through direct lobbying of the WHO. However, this does not demonstrate that the advocacy organisations persuaded governments to take action or influenced the strategies.

\section{Measuring the impact of advocacy on government policy}

Public health advocacy has been a significant driver of the policy agenda for several decades and this was acknowledged through formal inclusion in the WHO Ottawa Charter for Health Promotion in 1986. However, quantifying the impact of advocacy is challenging and there are few case study examples in the academic literature because advocates typically give low priority to evaluation of their efforts. What is more, it is difficult to assess the precise impact of advocacy on policy as it is rarely done in a controlled environment ${ }^{(23-25)}$. A range of factors influence the policy process ${ }^{(26)}$ and an issue usually only gets on to the public policy agenda when problems, opportunities and political support intersect and a critical mass in favour of the approach is reached. This might be long after the original advocacy activities have been carried out and it is not always possible to track back and confirm cause and effect. The pace of change in tobacco legislation illustrates how it may take decades for the outcomes of advocacy to materialise. Even with clear causal evidence in terms of the impact of tobacco smoke on health, strong public anti-smoking sentiment and one of the most effective advocacy campaigns in the world, it took 30 years to get legislation banning smoking in all workplaces ${ }^{(25)}$.

\section{Previous work on salt reduction in Australia}

There is strong evidence showing that reductions in population salt consumption can be achieved ${ }^{(27)}$, resulting in substantial health gains ${ }^{(28)}$. Leading Australian government health organisations ${ }^{(29)}$ recognise that reductions in population salt intake will reduce blood pressure-related disease, and advice to reduce sodium intake was included in national dietary guidelines for Australians in $1979^{(30)}$ and retained in the latest revision ${ }^{(31)}$. The National Heart Foundation of Australia's Tick programme promoting healthier food choices has been operating for 22 years and reports some success in driving industry to reduce salt in foods ${ }^{(32-34)}$. However, significant across-the-board reductions in the salt content of food have not been achieved $^{(35)}$. In 1995 , it was estimated that only $6 \%$ of men and $36 \%$ of women were meeting the maximum acceptable salt consumption target of $6 \mathrm{~g} / \mathrm{d}^{(36)}$.

In light of this, the Australian Division of World Action on Salt and Health (AWASH) launched its national Drop the Salt! campaign in May $2007^{(37)}$. As part of a broader strategy to try and reduce population salt intake to $6 \mathrm{~g} /$ person per d over five years, AWASH developed a media and advocacy strategy to encourage government to make salt reduction a national public health priority. The purpose of the present paper is to assess the impact of the AWASH advocacy strategy in influencing the government's agenda on salt from the launch of the campaign in May 2007 up to August 2010.

\section{Experimental approach}

\section{Objectives}

Prior to establishing the objectives of the advocacy strategy, a review of the evidence base for salt reduction, including existing Australian government policies and actions concerning dietary salt, was commissioned. This identified a number of policy initiatives including the Food Standards Australia New Zealand proposals for health claims and discussions about the merits of a regulatory approach to front-of-pack labelling and the national preventive health-care agenda. While there were no good assessments of population dietary salt intake, government documents indicated it was far in excess of dietary guidelines ${ }^{(38)}$. Yet, there were no State or Federal government policies specifically designed to reduce salt consumption.

The main objective of the AWASH advocacy strategy, initiated in May 2007, was therefore to persuade the Federal government to make salt reduction a national health priority by developing and implementing a coordinated government strategy to reduce salt intake in Australia. In particular, the campaign was advocating for government to: (i) lead a programme of work with the food industry to reduce salt in foods; (ii) fund a comprehensive social marketing campaign to raise consumer awareness; (iii) introduce a mandatory front-of-pack labelling system to clearly highlight the salt content of foods; and (iv) ensure adequate assessment and monitoring of sodium intake ${ }^{(39)}$.

\section{Activities}

In order to achieve the objectives of the advocacy strategy, ministers, specialist advisors and civil servants from both State and Federal government departments were targeted through a programme of work consisting of regular media releases, high-profile events, meetings with relevant government personnel, briefing specific government committees, submissions to government enquiries and regular communication with all stakeholders through the 
development of an extensive database of contacts and the distribution of regular update bulletins (Table 1).

\section{Monitoring inputs and outputs}

Records were kept of advocacy activities and any specific outputs that could be identified, as well as of government statements and actions relating to the objectives (Table 1).

Independent stakeholder research was commissioned to assess views on the role of AWASH in influencing the policy agenda. The study was conducted according to the guidelines laid down in the Declaration of Helsinki and all procedures involving human subjects were approved by University of Sydney Ethics Committee. Written informed consent was obtained from all participants. Thirteen stakeholders with known interests or responsibilities regarding dietary salt (seven food industry organisations, two departments from State and Federal government, one representative from each of an NGO,

Table 1 Timeline of activities and outcomes relating to AWASH advocacy strategy

\begin{tabular}{|c|c|c|c|}
\hline Time & Event/item & Media/main message & Outcomes \\
\hline May-Jul 2007 & AWASH Drop the Salt! launch & $\begin{array}{l}\text { First nationally coordinated } \\
\text { salt reduction initiative for } \\
\text { Australia }\end{array}$ & $\begin{array}{l}\text { Parliamentary Secretary for Health and } \\
\text { Ageing issued supportive media release }\end{array}$ \\
\hline Jan-Mar 2008 & $\begin{array}{l}\text { Salt and Children's Debate } \\
\text { chaired by Dr Norman Swan } \\
\text { during World Salt } \\
\text { Awareness Week }\end{array}$ & $\begin{array}{l}\text { Media release: 'Parents want } \\
\text { salt on the agenda and off } \\
\text { the table' }\end{array}$ & $\begin{array}{l}\text { Parliamentary Secretary for Health and } \\
\text { Ageing presented supportively } \\
\text { Discussions led to funding from NSW for } \\
\text { briefing paper }\end{array}$ \\
\hline Oct-Dec 2008 & $\begin{array}{l}\text { Commissioned background } \\
\text { paper on salt and health with } \\
\text { NSW Health funding }\end{array}$ & & $\begin{array}{l}\text { Report and recommendations for } \\
\text { government action used to inform FRSC } \\
\text { submission; distributed to state health } \\
\text { contacts }\end{array}$ \\
\hline Jan-Mar 2009 & Proposal to FRSC & $\begin{array}{l}\text { Proposed government action } \\
\text { on salt reduction }\end{array}$ & Recommended submission to AHMC \\
\hline Apr-Jun 2009 & $\begin{array}{l}\text { Submissions to Preventative } \\
\text { Healthcare Taskforce }\end{array}$ & $\begin{array}{l}\text { Indicated salt reduction should } \\
\text { be government priority }\end{array}$ & $\begin{array}{l}\text { Taskforce report highlighted AWASH, } \\
\text { recommended Healthy Food Compact to } \\
\text { engage with industry on reformulation }\end{array}$ \\
\hline Apr-Jun 2009 & Meeting with DoHA & & $\begin{array}{l}\text { AWASH may be involved in monitoring } \\
\text { progress }\end{array}$ \\
\hline Oct-Dec 2009 & $\begin{array}{l}\text { NHMRC Partnership Grant } \\
\text { proposal with NSW Health }\end{array}$ & $\begin{array}{l}\text { Monitoring project to inform } \\
\text { national salt reduction } \\
\text { policies }\end{array}$ & $\begin{array}{l}\text { Funding awarded: \$AUD } 1.6 \text { million NHMRC } \\
\text { partnership grant commencing } 2010\end{array}$ \\
\hline Oct-Dec 2009 & FHD announced & $\begin{array}{l}\text { Partnership with food industry } \\
\text { to improve food supply }\end{array}$ & $\begin{array}{l}\text { FHD to focus on reformulation including salt } \\
\text { reduction }\end{array}$ \\
\hline Oct-Dec 2009 & $\begin{array}{l}\text { Channel } 7 \text { Sunday Show: Salt } \\
\text { Assault }\end{array}$ & $\begin{array}{l}\text { AWASH Chairman appeared } \\
\text { on Sunday show with former } \\
\text { NSW Premier Bob Carr } \\
\text { discussing salt and health }\end{array}$ & $\begin{array}{l}\text { Meeting with Bob Carr; suggestion to write to } \\
\text { existing NSW Premier proposing food } \\
\text { forum }\end{array}$ \\
\hline Jan-Mar 2010 & $\begin{array}{l}\text { Correspondence with } \\
\text { Parliamentary Secretary for } \\
\text { Health and Ageing }\end{array}$ & $\begin{array}{l}\text { Proposal to collaborate on } \\
\text { monitoring of dietary sodium }\end{array}$ & $\begin{array}{l}\text { Response declined collaboration on survey } \\
\text { but acknowledged role of NHMRC } \\
\text { partnership project in monitoring } \\
\text { outcomes of the FHD }\end{array}$ \\
\hline Feb 2010 & $\begin{array}{l}\text { AWASH published report on } \\
\text { salt levels in foods }\end{array}$ & $\begin{array}{l}\text { Media release 'New research: } \\
\text { time for Australia to target } \\
\text { salt' }\end{array}$ & $\begin{array}{l}\text { Widespread coverage highlighting need for } \\
\text { government targets as part of Salt } \\
\text { Awareness Week }\end{array}$ \\
\hline Mar 2010 & Mark Butler announcement & & FHD salt targets for bread/breakfast cereals \\
\hline Apr-Jun 2010 & & & $\begin{array}{l}\text { Government's response Taking Preventative } \\
\text { Action confirmed commitment to salt } \\
\text { action through FHD }\end{array}$ \\
\hline Jul-Aug 2010 & $\begin{array}{l}\text { NSW Premier's Forum on Fast } \\
\text { Foods - stimulated by joint } \\
\text { letter from AWASH Chair } \\
\text { and NHF }\end{array}$ & $\begin{array}{l}\text { AWASH Chair presented } \\
\text { evidence base for salt } \\
\text { reduction }\end{array}$ & $\begin{array}{l}\text { Quick Service Restaurant Reference Group } \\
\text { to consider labelling, reformulation and } \\
\text { consumer education on fast foods, to be } \\
\text { chaired by NSW Food Authority, } \\
\text { announced }\end{array}$ \\
\hline
\end{tabular}

AWASH, Australian Division of World Action on Salt and Health; FRSC, Food Regulation Standing Committee; DoHA, Department of Health and Ageing; NHMRC, National Health and Medical Research Council; FHD, Food and Health Dialogue; AHMC, Australian Health Ministers Council; NHF, National Heart Foundation of Australia; NSW, New South Wales. 
academic and consumer advocacy organisation) were interviewed during November 2009. The interviews were structured around three themes: (i) organisational position of the stakeholder in the context of broader health priorities; (ii) views on impact strengths and weaknesses in relation to the AWASH Drop the Salt! campaign, the food industry's response to salt reduction and the government's response to salt reduction; and (iii) views on the role of AWASH within the George Institute for Global Health (hereafter referred to as 'the George Institute'). Topic areas and questions were used to structure the interviews but participants were able to raise whichever issues they felt were important. Interviews were recorded digitally and a summary of responses prepared following each interview. Common themes were identified in general and for each stakeholder group (industry, government and consumer/NGO).

\section{Results}

\section{Media coverage}

The twenty-five media releases issued represented a mixture of proactive action such as launching the results of new surveys and opportunistic action such as responding to academic journal articles or international news items. Eighteen out of the twenty-five included a specific call for government action. Monitoring put together by Google analytics demonstrated that most resulted in widespread print, radio and television coverage. The scale of coverage can be demonstrated through the media release issued as part of International Salt Awareness Week in February $2010^{(40,41)}$ which resulted in forty print and Internet articles, thirty-three radio pieces and twenty-one television features; thirteen of which included interviews with the AWASH Chairman or Senior Project Manager. AWASH was not able to monitor the impact of media coverage on government policy but the stakeholder research suggested it was a likely influence.

\section{Government statements supporting the need for salt reduction}

Two government statements on salt were made following invitations to participate in campaign events ${ }^{(42)}$. Following the 2008 World Salt Awareness Week event which the new Parliamentary Secretary for Health and Ageing attended, AWASH representatives were invited to a follow-up meeting in Canberra for further discussions. No specific action resulted from this. However, a meeting between AWASH and NSW Health's Chief Health Officer, arranged following the Drop the Salt! event, resulted directly in funding to commission a review of the evidence base and effectiveness of salt interventions. This was used to inform a briefing paper to the Food Regulation Standing Committee (FRSC) with proposals for a salt reduction strategy discussed in March 2009. FRSC supported the proposals, but referred the matter to Australian Health Ministers Council, which has still not considered the issue formally.

The Drop the Salt! campaign was specifically acknowledged in a number of government committee reports following submissions and informal communications with committee members ${ }^{(43,44)}$. Subsequent reports made recommendations to work with the food industry to reduce salt including through the setting of voluntary targets for food categories ${ }^{(45,46)}$. The government response to National Preventative Healthcare Task Force recommendations in May 2010 ${ }^{(47)}$ confirmed that Australians were eating nearly twice the recommended amount of salt and supported initiatives to influence the supply and demand of foods towards healthier consumption patterns.

\section{New government policies and programmes}

The present research demonstrated that the Drop the Salt! campaign had had an impact in relation to four new government policy initiatives that could be attributed wholly or partially to the campaign (Table 2). An AWASHcommissioned policy paper and engagement with NSW Health led to the FRSC discussing salt in March 2008. The Food and Health Dialogue (FHD) was formally announced in October $2009^{(48)}$ and announced voluntary targets for salt levels in bread and breakfast cereals in March 2010 ${ }^{(49)}$. Discussions with NSW Health following the AWASH Salt Awareness Week event in 2009 led to \$AUD 250000 partnership funding towards a 5-year, \$AUD 1.6 million National Health and Medical Research Council (NHMRC) grant awarded to the George Institute in 2010 to monitor sodium consumption patterns and develop policy. Finally, the NSW Premier's Forum on Fast Foods in August 2010, which resulted in menu labelling legislation for fast foods (Food Regulation 2010 of the Food Act 2003), was a direct outcome of a joint letter from the AWASH Chairman and the National Heart Foundation. While the implemented legislation does not currently focus on salt, the Act specifies a review after a year which requires consideration of expansion to incorporate salt and fat in the future.

\section{Key findings from stakebolder research}

Independent stakeholder research provided further indications that the Drop the Salt! campaign helped put salt reduction on the government's agenda as well as highlighting perceived strengths and weaknesses of the campaign.

Table 2 Policy outputs related to the Drop the Salt! campaign Outputs wholly or partly attributable to advocacy strategy:

1. FRSC discussions on need for government action on salt reduction - March 2008

2. \$AUD 1.6 million NHMRC Partnership Project awarded to the George Institute for salt reduction policy development and monitoring - October 2009

3. FHD focus on establishing targets for salt - October 2009

4. NSW Premier's Forum on Fast Foods - August 2010

FRSC, Food Regulation Standing Committee; FHD, Food and Health Dialogue; NSW, New South Wales. 
Most stakeholders interviewed identified media coverage as the main strength of the campaign and felt this had a direct impact on raising the profile of salt with government as well as reinvigorating industry salt reduction activities. The report said 'stakeholders all agreed that AWASH has excelled at generating media coverage and creating clever headlines. Press coverage and TV programs are seen as impactful'. One food industry contact observed that any food company would have been proud to have achieved the brand recognition that AWASH managed to secure in a relatively short time scale. All stakeholders appreciated that AWASH had drawn people together to facilitate dialogues across the health and industry sectors and provided evidence-based arguments and technical information in support of salt reduction.

In particular, the Federal government's FHD initial focus on salt was considered substantively attributable to AWASH and the fact that it had demonstrated the feasibility of large-scale change through industry engagement on salt reduction. However, AWASH's exclusion from the Dialogue was seen by some as limiting its influence on salt reduction both immediately and in the future. Several people observed that the 'lobbyist stance' had made AWASH an 'outsider' to policy solutions. The report said: 'Stakeholders perceived that AWASH's exclusion from the Food and Health Dialogue would be a major barrier to influence in the future'. There was some surprise at this omission and speculation as to why this might have occurred. One person suggested that the adversarial approach taken by AWASH in the media may have prompted the decision. Another view was that other NGO had resisted AWASH's inclusion on the basis of 'patch protection'.

The focus on salt as a single nutrient (as opposed to taking a whole food approach) was seen by several people as a weakness in relation to getting the issue on the government's agenda in view of its primary focus on obesity. However, others saw this as a benefit in that it allowed for clearer communication. While some tensions between other NGO and government departments were observed, on the whole, relationships between AWASH and most organisations were characterised as positive, trusting and supportive, easy and open to finding new ways forward.

The report concluded that on balance the AWASH adversarial media had made a significant contribution to increasing the profile for salt as a public health issue, with both government and industry stakeholders having subsequently increased their support for salt reduction. 'It is hard to assess cause and effect but AWASH certainly played a major role in raising salt up the government agenda' (government stakeholder).

\section{Discussion}

In just three years, the AWASH strategy helped to raise the profile of salt on the government's agenda at both State and Federal levels. Although it is not possible to definitively attribute cause and effect, the independent stakeholder research has provided a fair indication of the likely effects of the campaign. This research suggests that a multi-faceted advocacy strategy has elevated the importance of salt for government. Building trust with the food industry and demonstrating the potential for collaborative action to reduce salt in foods has been a key factor in this success. However, while the outcomes demonstrate increased government activity related to salt, salt reduction is still not a government priority. The FRSC discussions on salt did not deliver any tangible output, a proposal to include $24 \mathrm{~h}$ urine assays in the National Nutrition Survey was ignored and progress with the FHD is glacial. The new legislation on calorie labelling for menus introduced in February 2011 is a positive outcome of the NSW Forum but this does not currently address salt.

There is strong evidence ${ }^{(50-53)}$ that government-led salt reduction programmes are an extremely cost-effective way of reducing premature deaths from CVD. The few salt targets set to date in Australia and the opaque process are concerning. The US National Salt Reduction Initiative used the UK Food Standards Agency targets to inform its target-setting process and covered eighty-five categories of restaurant and processed foods in just over one year ${ }^{(54)}$ with sixteen leading food manufacturers and restaurant chains publicly committing to them.

There are clear lessons here for the Australian government's FHD but also for the AWASH advocacy strategy. The FHD ${ }^{(55)}$ could have adopted interim targets derived overseas and initiated immediate sector-wide action while putting in place a parallel process to make any local adaptations that might be required. It would then have been possible to make significant progress in less than a year. Likewise, rather than focusing all its efforts on getting the government to set targets, AWASH could have promoted interim targets and monitored companies' progress against these goals. The main barrier to this was that the food industry argued that UK or US targets were unacceptable, thus very effectively delaying progress. Annual changes in key government personnel also prevented effective relationship building through which to promote the importance of salt reduction in Australia.

\section{Conclusion}

The establishment of government targets for salt levels in foods was one of the priority campaign messages for AWASH. However, successfully achieving this objective has not had the desired impact. A significant reduction in population salt intake requires much stronger leadership (backed by resources) from government as part of a coordinated national salt reduction strategy. The challenge for public health advocacy now is to redefine its own role in light of the new policy initiatives that have emerged. 
In view of the limited impact of actions to date, new advocacy strategies will need to be developed to encourage government to make more concerted effort. In addition to a more effective process for establishing targets for salt levels in foods, a social marketing strategy to change consumer behaviour and clear labelling of foods so that it is easy to understand the salt content are also needed. Finally, the George Institute's NHMRC-funded project will provide new evidence on Australian salt intakes and salt levels in foods. However, longer-term government commitment is essential to ensure regular monitoring, effective targeting of policies and the potential to demonstrate a change in salt intakes. Salt reduction has the potential to save thousands of lives each year by reducing the risk of heart attack and stroke. It is therefore a public health opportunity that the Australian government cannot afford to overlook.

\section{Acknowledgements}

Source of funding: The activities of AWASH are funded in part through an NHMRC programme grant and since 2010 through an NHMRC partnership grant. J.W. is supported by a National Heart Foundation and Stroke Foundation Postdoctoral Research Fellowship; E.D. is supported by a Sydney Medical School Foundation scholarship; and B.N. is supported by an Australian Research Council Future Fellowship. Conflicts of interest: B.N. is the Chair, J.W. is the Senior Project Manager and E.D. is the Research Officer for AWASH. J.W. previously led the team responsible for implementing the UK government's salt reduction strategy. The food policy team at the George Institute for Global Health has received financial support from The Australian Food and Grocery Council through its NHMRC Project Partnership Grant and Bupa Australia to support the development of the FoodSwitch healthy eating food application. J.W. was supported by the company Mitsubishi Tanabe Pharma to do a series of lectures on salt reduction in Japan in 2012. B.N. is a member of the Pepsico Scientific Advisory Committee. Authors' contribution: J.W. designed and implemented the research as part of her PhD studies which were supervised by B.N. and S.C. S.K. was commissioned to do the independent stakeholder analysis and ensured that the findings were adequately represented here. She has since been appointed to work part time at the George Institute. E.D. provided support with documenting the outcomes. All authors commented on and agreed drafts of the paper.

\section{References}

1. Australian Government, Department of Health and Ageing \& National Health and Medical Research Council (2006) Nutrient Reference Values for Australia and New Zealand. Canberra: Commonwealth of Australia.
2. National Health and Medical Research Council (2003) Dietary Guidelines for Australian Adults. Canberra: Commonwealth of Australia.

3. Havas S, Dickinson B \& Wilson M (2007) The urgent need to reduce sodium consumption. JAMA 298, 1439-1441.

4. Intersalt Cooperative Research Group (1988) Intersalt: an international study of electrolyte excretion and blood pressure: results for 24 hour urinary sodium and potassium excretion. BMJ 329, 319-328.

5. Asia Pacific Cohort Studies Collaboration (2003) Blood pressure and cardiovascular diseases in the Asia-Pacific region. J Hypertens 21, 707-716.

6. Australian Institute of Health and Welfare (2005) Health Expenditure Australia 2003-4. Canberra: AIHW.

7. MacGregor G (1997) Salt - more adverse effects. Am J Hypertension 10, 5 Pt 2, 37S-41S.

8. Law MR, Frost CD \& Wald NJ (1991) By how much does dietary salt reduction lower blood pressure? I - Analysis of observational data among populations. BMJ 302, 811-815.

9. Law MR, Frost CD \& Wald NJ (1991) By how much does dietary salt reduction lower blood pressure? II Analysis of observational data within populations. BMJ 302, 815-819.

10. MacGregor GA \& Sever PS (1996) Salt - overwhelming evidence but still no action: can a consensus be reached with the food industry? BMJ 312, 1287-1289.

11. Webster JL, Dunford EK, Hawkes C et al. (2011) Salt reduction initiatives around the world. J Hypertens 29, 1043-1050.

12. Campbell NR, Neal BC \& MacGregor GA (2011) Interested in developing a national programme to reduce dietary salt? J Hum Hypertens 25, 705-710.

13. UK Food Standards Agency (2007) Salt. http://www.food. gov.uk/healthiereating/salt/ (accessed January 2011).

14. UK Food Standards Agency (2010) Dietary sodium levels survey. http://www.food.gov.uk/science/dietarysurveys/ urinary (accessed December 2010).

15. UK Food Standards Agency (2007) Agency research reveals a drop in British salt consumption. http://www.food. gov.uk/news/newsarchive $/ 2007 / \mathrm{mar} /$ saltresearchmar07 (accessed January 2011).

16. Canadian Sodium Working Group (2010) Sodium Reduction Strategy for Canada: recommendations from the sodium working group. http://wwwhc-scgcca/fn-an/nutrition/ sodium/strateg/index-engphp (accessed January 2011).

17. New York City Department of Health and Mental Hygiene (2010) National Salt Reduction Initiative. http://www. nyc.gov $/ \mathrm{html} / \mathrm{doh} / \mathrm{html} /$ cardio/cardio-salt-initiative.shtml (accessed February 2011).

18. Consensus Action on Salt and Health (2008) Homepage. http://www.actiononsalt.org.uk/ (accessed January 2011).

19. Center for Science in the Public Interest (2008) Salt: The Forgotten Killer. http://www.cspinet.org/salt/ (accessed December 2010).

20. World Action on Salt and Health (2007) Media Launch. http://worldactiononsalt.com/media/Media_coverage/ Archive_Wash_Launch.htm (accessed December 2010).

21. Department of Health (2009) The Chief Medical Officer's Public Health Awards 2009: Silver Winner Consensus Action Salt and Health. http://www.cmoawards.org.uk/ winners.aspx (accessed December 2010).

22. He FJ \& MacGregor GA (2008) A comprehensive review on salt and health and current experience of worldwide salt reduction programmes. J Hum Hypertens 23, 363-384.

23. Chapman S (1993) Unravelling gossamer with boxing gloves: problems in explaining the decline in smoking. BMJ 307, 429-432.

24. Chapman S (2001) Advocacy in public health: roles and challenges. Int J Epidemiol 30, 1226-1232. 
25. Chapman S \& Wakefield M (2001) Tobacco control advocacy in Australia: reflections on 30 years of progress. Health Educ Behav 28, 274-289.

26. Nutley S \& Davis H (2007) Using Evidence: How Research Can Inform Public Sector Services. Bristol: Policy Press.

27. Joint Health Surveys Unit (2006) An Assessment of Dietary Sodium Levels Among Adults (Aged 19-64) in the General Population, Based on Analysis of Dietary Sodium in 24 hour Urine Samples. London: National Centre for Social Research.

28. Centre for Health Economics Research and Evaluation (2008) Scenario Modelling of Potential Health Benefits Subsequent to the Introduction of the Proposed Standard for Nutrition, Health and Related Claims. Report developed for Food Standards Australia New Zealand. Sydney: CHERE.

29. National Blood Pressure Advisory Committee (2007) Salt and Hypertension: A Paper for Health Professionals. Canberra: National Heart Foundation of Australia.

30. National Health and Medical Research Council (1982) Report on the Working Party on Sodium in the Australian Diet. Canberra: Australian Government Publishing Service.

31. Commonwealth Department of Health (1981) Dietary Guidelines for Australians. J Food Nutr 38, 111-119.

32. National Health and Medical Research Council (1992) Dietary Guidelines for Australians. Canberra: Australian Government Publishing Service.

33. National Heart Foundation of Australia (2010) Tick Program. http://www.heartfoundation.org.au/sites/tick/Pages/default. aspx (accessed November 2010).

34. Young L \& Swinburn B (2002) Impact of the Pick the Tick food information programme on the salt content of food in New Zealand. Health Promot Int 17, 13-19.

35. Williams P, McMahon A \& Boustead R (2003) A case study of sodium reduction in breakfast cereals and the impact of the Pick the Tick food information program in Australia. Health Promot Int 18, 51-56.

36. Australian Division of World Action on Salt and Health (2008) AWASH Sausage Sizzle Key Findings. http://www. awash.org.au/documents/Sausage_Sizzle_Key_Findings_July_ 2008.pdf (accessed December 2010).

37. Wills R \& Duvernet L (1996) Update on the sodium levels in Australian processed foods. Food Aust 48, 568-569.

38. Beard TC, Woodward DR, Ball PJ et al. (1997) The Hobart Salt Study 1995: few meet national sodium intake target. Med J Aust 166, 404-407.

39. Australian Division of World Action on Salt and Health (2007) Report of Drop the Salt! campaign launch and networking lunch. http://www.awash.org.au/ documents/ Drop_the_Salt_Campaign_Launch_and_Networking_Lunch_ Report.pdf (accessed December 2010).

40. Webster J, Dunford E, Huxley R et al. (2009) The development of a national salt reduction strategy for Australia. Asia Pac J Clin Nutr 18, 303-309.

41. Australian Division of World Action on Salt and Health (2010) Media release: New research: time for Australia to target salt. http://awash.org.au/media_release_2010_02_03. html (accessed January 2011).
42. Webster JL, Dunford EK \& Neal BC (2009) A systematic survey of the sodium contents of processed foods. Am J Clin Nutr 91, 413-420.

43. Parliament House (2007) Media Release: Drop the SaltDrop the Pressure. Canberra: Parliament House.

44. Sydney Morning Herald (2008) Australian diets too salty. http://www.smh.com.au/lifestyle/wellbeing/australian-diettoo-salty-20090403-9mya.html (accessed January 2011).

45. taste.com.au (2008) Reducing salt should be a priority alongside reducing obesity, alcohol and tobacco. http:// www.taste.com.au/news + features/articles/1123/salt + as + $\mathrm{bad}+\mathrm{as}+$ obesity + tobacco + nutritionist (accessed January 2011).

46. Preventative Healthcare Taskforce (2009) Australia: the healthiest country by 2020. National Preventative Health Care Strategy - the roadmap for action. http://www. preventativehealth.org.au/internet/preventativehealth/ publishing.nsf/Content/CCD7323311E358BECA2575FD000 859E1/\$File/nphs-roadmap.pdf (accessed December 2010).

47. Australian Parliament Standing Committee on Health and Ageing (2009) Weighing it Up: Obesity in Australia. Canberra: Printing and Publishing Office, House of Representatives.

48. Department of Health and Ageing (2010) Taking Preventative Action. A response to Australia: the healthiest country by 2020. A report of the National Preventative Healthcare Taskforce. http://www.preventativehealth.org.au/internet/ preventativehealth/publishing.nsf/Content/6B7B17659424 FBE5CA25772000095458/\$File/tpa.pdf (accessed December 2010).

49. Department of Health and Ageing (2009) Nutrition and Healthy Eating - Food and Health Dialogue. http:// www.health.gov.au/internet/main/publishing.nsf/Content/ food-health-dialogue (accessed January 2011).

50. Department of Health and Ageing (2010) Food and Health Dialogue. Salt Reduction Targets Agreed. http://www.health. gov.au/internet/ministers/publishing.nsf/Content/mr-yr10-mbmb022.htm?OpenDocument (accessed January 2011).

51. Asaria P, Chisholm D, Mathers C et al. (2007) Chronic disease prevention: health effects and financial costs of strategies to reduce salt intake and control tobacco use. Lancet 370, 2044-2053.

52. World Health Organization (2007) Reducing Salt Intake in Populations. Geneva: WHO.

53. Smith-Spangler CM, Juusola JL, Enns EA et al. (2010) Population strategies to decrease sodium intake and the burden of cardiovascular disease. Ann Intern Med 152, 481-487.

54. New York City Department of Health and Mental Hygiene (2010) Cut the Salt - Get the Facts. The National Salt Reduction Initiative. http://www.nyc.gov/html/doh/ downloads/pdf/cardio/cardio-salt-nsri-faq.pdf (accessed January 2011).

55. Department of Health and Ageing (2009) Food and Health Dialogue announced. http://www.health.gov.au/internet/ ministers/publishing.nsf/Content/mr-yr09-mb-mb030.htm? OpenDocument (accessed January 2011). 